\title{
Implementation Of Self-Regulated Learning Model In E-Learning English Writing
}

\author{
Laode Nggawu, Hartati Muchtar, Khaerudin, M. Syarif Sumantri
}

\begin{abstract}
This Academic article discusses the implementation of self-regulated learning model in e- learning English Writing, especially on enriching writing skill. This study uses a qualitative method. The discussion of this article uses many points of views of self-regulated model learners, such as Albert Bandura, Barry Zimmerman, Anananita Bramuci, Popa Daniela, and Ernesto Panadero. According to the authors' interpretation, the discussion shows several results. (1) English writing skills require serious effort and practice in formulating, developing and analyzing ideas, especially for second / foreign language learners. (2) The understanding of English language grammar and vocabulary is indispensable for second / foreign language learners. (3) The self-regulated learning model can increase the learning motivation because this model encourages students to acquire knowledge and skills on their own voluntarily; and (4) learners who have high self-regulated learning, will have good learning outcomes as well.
\end{abstract}

Index Terms: Self Regulated Learning, Writting Skills, eLearning English Writing.

\section{INTRODUCTION}

Learning is defined as a deliberate effort by educators to support student learning activities [1]. Language learning requires an appropriate and effective strategy. A teacher should know and understand strategies in language learning to develop teaching skills and also develop learner skills [2]. With these strategies, it is hoped that the goal of language learning can be achieved. As is known the purpose of learning English is to develop language skills, both orally and in writing.

The fact shows that most students think that learning to write especially English is very difficult and the learning process is boring [3]. Student difficulties can be found when they have to transfer ideas from Indonesian to English. The second difficulty is that students can not determine the meaning of words or phrases that exist in a English written text. In addition, the learning process is still in traditional way by emphasizing the student's writing not on the process that should be done [4]. The students immediately practice writing without learning how to write. Lecturers usually provide several kinds of topics and ask the learner to choose one and they immediately write. Furthermore, learning to write in English has its own challenges and problems, especially for foreign / second language learners. Flowerdew [5] mentions several issues when learning to

Revised Manuscript Received on April 19, 2019.

Laode Nggawu, Educational Technologi, Universitas Negeri Jakarta, Jakarta, Indonesia. Lecturer in Halueelo University, Makasar, Indonesia

Hartati Muchtar, Educational Technologi, Universitas Negeri Jakarta, Jakarta, Indonesia.

Khaerudin, Educational Technologi, Universitas Negeri Jakarta, Jakarta, Indonesia.

M. Syartif Sumantri, Educational Technologi, Universitas Negeri Jakarta, Jakarta, Indonesia. write English for foreign / second learner, such as lack of facilities to express ideas, take long time to write, lack vocabulary, and first language influence. Grammatical aspects are also of concern in English writing learning, especially for second / foreign language learners. Truscott [6] asserted that a teacher should be able to provide correct correction of writing errors, taking into account such things as correction must be selective and carried out on the basis of learner development, correction made consistently and effectively. Based on this view, the correction model may differ from learner one to another, so a teacher needs to monitor the progress of each learner. In essence, the correction has the same function as feedback. Success and failure of feedback can be influenced by several things, such as the class context, the type of error, the level of student ability, and the type of writing [7]. In addition, the identification of teacher's style or model of learning by teachers is very important because it can help students easier in following the learning process. This can contribute to the well development of students' abilities [8]. Therefore, in addition to the ability of teachers to teach is also required appropriate learning model in developing students' writing skills in English.

According to Gagne, cited by Gredler [9] that an important process in achieving the objectives of learning is to identify the internal situation and the learners. Woolfook [10] suggests that the factor of the inner self is self-efficacy, i.e. one's belief in the ability of self to face and solve problems effectively. Learners who have a high self-efficacy can face challenges in following the lecture; do not feel hesitant because $\mathrm{He}$ has a full confidence with his ability. Individuals like this according to Bandura [11] will be able to face problems and be able to rise from the failure that $\mathrm{He}$ experienced.

In addition to interest, learning motivation needs to be owned by the students. One of the role of teacher / lecturer is to improve students' learning motivation. This is based on research results that show that motivation is directly significant to learning outcomes. High motivation makes students have a passion for continuing learning that gives good results on the learning achievement. Vice versa, low motivation can decrease the spirit of learning and provide learning outcomes that are not good.

Based on the description above, there are four things to note, especially in learning writing skills, namely the model of learning, interest, motivation, and the role of teachers. These four things are interconnected. Good learning model and good teacher model will generate high interest and

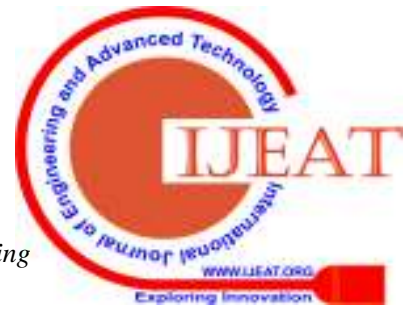


motivation. In other words, the right learning model will make students become happy to learn and continuously learn, so their competence is always increasing.

To achieve the desired learning objectives in learning writing, then one of the appropriate learning model and suitable to meet these demands is self-regulated learning model. Powers [12] states that in learning, one of the most important things to understand is how self-regulated learning occurs during the learning process. According to Powers [13] that self-regulated learning is a meaningful learning derived from learners who actively participate in the learning. This learning model can increase students' selfconfidence, interest, and motivation. The self-regulated learning model is a model that can make students discover and understand difficult concepts. According to this view in self-regulated learning that one of the goals of teaching is to free the students from their need for the teacher, so that they can continue to study independently throughout their lives. By applying this learning model, it is expected to eliminate saturated and boredom in learning, so that students can continue to study wherever and whenever. Learning becomes their need and it is a very interesting activity. Therefore, the self-regulated learning model allows to be applied in the learning process.

Based on the description above, this paper will discuss the English Writing Learning and the relationship between the implementation of self-regulated learning model and English language ability, especially on the development of English writing ability.

\section{METHOD OF STUDY}

This study uses a qualitative method. Qualitative research is multimethod in focus, involving an interpretive, naturalistic approach to its subject matter. This means that qualitative researchers study things in their natural settings, attempting to make sense of, or interpret, phenomena in terms of the meanings people bring to them [14]. Qualitative researchers use a variety of methods to develop deep understandings of how people perceive their social realities and in consequence, how they act within the social world. For example, diary accounts, open-ended questionnaires, documents, participant observation, and ethnography. This study used literature review method which collected some resources from books, articles, and scientific journal. This research provide information linked on the self regulated learning Model for giving to the reader aboutbasic knowledge to the topic.

\section{RESULTS AND DISCUSSION}

This section is divided into two discussions, e.g. learning to write in English and the relationship of application of self-regulated learning model and the development of writing ability. The two subjects are described as follows.

\subsection{English Language Learning}

Zahed-Babylon and Mahdi [15] suggest that language learning styles and strategies appear to be the most important variables in influencing the development of second language learner abilities. Learning to write in English requires a proper learning model, while taking into account the characteristics of the learner. Chand [16] adds that academic writing requires serious effort and practice in composing, developing, and analyzing ideas. This will work smoothly if supported by appropriate strategies, techniques, and writing skills.

Taylor [17] asserted that if we want to write then first we must already know about what we will write. In order to write well and fluently, students must have sufficient experience of what is written and knowledge of the language foundation [18]. Foundation of basic English can be an understanding of grammatical structure, vocabulary, and tense terms [19]. In addition, a proper approach in learning how to write in English, especially for non-native speakers, should also be chosen appropriately.

Based on the view above, learning English writing skills has somewhat different ways between native speakers of English and non-native speakers, such as in Indonesia for Indonesian students, need to do a lot of practice to become a good writer in English. The exercises need to be gradually done from the easiest to the hardest, and so on. In addition, to write in English, need to know and learn first about the English grammar and vocabulary. Next, the students need to do various processes in writing, like choosing topics, brainstorming, outline, drafting, review, revising, editing, and so on.

Fitzpatrick [20] mentions that in teaching and improving writing skills requires a process, namely the process of writing conducted by students, ranging from prewrite activities to the final. Therefore, it takes time for students to get and organize their ideas. Process and communicative approaches are important in teaching English writing skills, such as modeling paragraphs, controlled compositions, free writing, sentence-making exercises, and paragraph analysis [21].

Thing that also very important to develop the students' skills in writing is good role of teachers / lecturers. Teachers / lecturers should be able to demonstrate important aspects of writing, such as related to the type of writing and how to compose a good sentence, and arrange paragraphs into a good writing. Teachers / lecturers must also always motivate students to enjoy writing activities. In addition, support from teachers / lecturers on student activities is also very necessary. In fact, teachers / lecturers should always respond well to the writing activities of students, provide feedback, provide evaluation, and others.

Raimes [22] gives seven questions to be answered as a technique for planning writing classes, that is a) how writing can help students in learning a second language, b) how I can find the right topic, c) how can I help to make something meaningful, d) who will read what the student wrote, e) how students can work together in the classroom, f) how much time should be given to the student, and g) what I do when there is error. Based on the seven basic questions above that should be answered well by the teacher / lecturer, then something that becomes the main concern is that writing activities that can help improve the skills and knowledge of students about English. To help it, teachers / lecturers should be able to determine the right topic. The

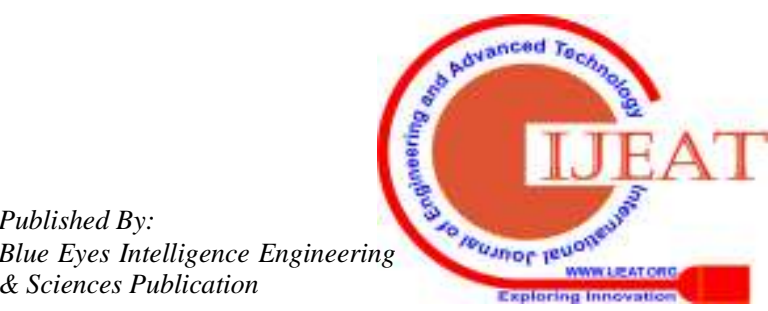


exact topic is certainly something that is suitable for students, interesting, and not difficult, especially related to getting references in writing. The role of teacher / lecturer is very meaningful to produce useful writing.

West [23] introduces the process of writing. First, start writing by making skeleton outline. The skeleton outline or The framework chart contains the issues that become writing reference. Second, the skeleton outline need to be revised back so that nothing would be missed. Third, start drafting. Fourth review of the draft. Fifth, reorganize according to the review of the draft. Sixth, make the final writing in accordance with the repair errors ranging from big mistakes to small errors. In making paragraphs, it must meet the unity and coherent conditions. Unity means focusing only on one main idea. Between one sentence with the other, supporting each other in explaining a central idea. The concept of coherence implies that between paragraphs one to another should be arranged sequentially (not jumping ideas) with one idea/topic. The cohesion aspect also becomes an important part of writing. To create the cohesion aspect, it is worth noting the following two things: pronouns and word repetition. 3.2 The Relationship of the Self Regulated Learning Model Application and Development of Writing Ability

Self-regulated learning evolved from social cognitive theory, particularly the social cognitive of Bandura [24]. It is as revealed by Powers [25] that self-regulated learning is viewed through social cognitive constructing learning theory developed by Albert Bandura and others in the 1960s and 1970s. According to this view, one of the objectives of learning is to free students from their need for teachers, so that they can continue to study independently throughout their lives. According to Zumbrunn, et al. [26] self-regulated learning is a process that helps students to manage themselves, thoughts, behaviors, and emotions to successfully drive their learning experiences. Bramuci [27] emphasizes that self regulated learning is able to assist teaching in identifying appropriate developmental methods from both the plan point of view and the learning process.

Self-regulated learning includes aspects of cognitive, metacognitive, attitudes, motivation, affective in learning [28]. Therefore, this model is very important in the learning process, including in learning to write English. High selfregulation will have a high learning motivation. Students with high self-regulation are always aware of their development. Students' learning outcomes will increase if they have good self-regulation, such as being aware of learning goals, controlling and organizing themselves always to learn, follow the rules, and organize learning plans well [29]. People who do self-regulated learning are referred to as self-regulated learner or self-regulated learners.

One of the goals of learning is to prepare students to be able to learn for life. Departing from this perspective, pioneering and developers of the self-regulated learning model provide the concept in the model, i.e. students must have a combination of knowledge, motivation to learn, and willingness to learn independently and effectively. Therefore, to be a self-regulated learner, there are three factors that must be understood and owned, namely knowledge, motivation, and self-discipline [30]. Students need knowledge of themselves, their subjects, their duties, the learning strategies, and the learning contexts they will apply. Students also need to be motivated to learn. They find many tasks in school interesting because they value learning, not just work well in the eyes of others. In addition to knowledge and motivation, students also need volition or self-discipline. Woolfolk [31] defines volition as an effort to protect the opportunity to achieve goals by applying selfregulated learning. Self-regulated learners know how to protect themselves from distraction, where they must learn to avoid being interrupted. They know how to cope when they feel anxious, sleepy, or lazy.

Powers [32] asserts that in self-regulated learning, educators must make students pro-active in learning. Students should be given many opportunities, beliefs, freedoms, and choices in the learning process. This can lead independent learners, so they are not always dependent on the teacher. They can learn on their own wherever they like, like at home, at school, and can also learn at any time. The students learn according to their own will and do not need to be forced or should always be controlled. Nevertheless, the existence of the teacher remains very important and necessary. Ferreira and Ana Malgarida [33] say that the role of teachers is very important in generating self-regulation of students or developing a strategy in self-regulated learning because of systematic interaction and mutual need between students and skill models, as well as between students and teachers. Teachers can help develop self-regulation of their students by suggesting or motivating them with some questions, such as "Do you already know the purpose of the learning tasks given?" And "What strategies are effective for you to achieve the learning goals?" [34]. This is done to generate motivation and stimulate students to think, both think smartly about the future and the plans that will be done.

There are four assumptions about self-regulated learning used by Wolters et al. [35] First; the assumptions are active and constructive. Students as active participation constructive in the learning process, whether they actively construct the understanding, goals, and strategies of information available in the environment and their own mind. Second, self-regulated learning is the potential for control. Students are able to monitor, control, regulate certain aspects of cognitive, motivational and behavioural environmental characteristics where possible. The third is the assumption of goals, criteria, or standards. The assumption is used to assess whether the process should proceed when necessary when some criteria or standards change. Fourth is the assumption that the activity in selfregulated learning is the mediator between the personal and the characteristics of the context and the achievement or the real performance. Self-regulated on the cognitive, motivation, and behavior of individuals is an intermediary of relationships between individuals, contexts, and even achievements. Based on the above assumptions, selfregulated learning is an active and constructive process that sets the goal for the learning process and tries to monitor, 
regulate, and control cognition, motivation, and behavior, which are all directed and driven by objectives and adapted to environmental context.

Students with self-regulation at a high level will have good control in achieving their academic goals. Selfregulation applied in self-regulated learning requires students to focus on the process of self-regulation in order to gain academic ability. According to Zimmerman [36], selfregulated learning consists of setting the three general aspects of academic learning, namely cognition, motivation, and behavior. In accordance with the above strategy aspect, furthermore Wolters et al. [37] describe in detail the application of strategy in every aspect of self-regulated learning as follows:

First, strategies for controlling or regulating cognition include activities and metacognitions that require individuals to be involved in adapting and changing their cognition. A rehearsal strategy, elaboration, and organization can be used by individuals to control their cognition and learning process.

Second, a strategy to regulate motivation involves a purposeful activity in starting, organizing and adding the will to start, preparing for the next task, or completing a specific activity or purpose. Motivational regulation is all thoughts, actions or behaviors in which students attempt to influence the choice, effort, and persistence of their academic duties. The motivational regulation includes mastery self-talk, extrinsic self-talk, relative ability self-talk, relevance enhancement, situational interest enhancement), self-consequence, and environmental structuring.

Third, the strategy to regulate behavior is an individual effort to control the behavior itself. Each can observe, monitor, and attempt to control and regulate and as such generally can be regarded as self-regulatory for the individual. Behavior regulation includes business regulation, time and study environment, and help-seeking.

There are some self-regulated learning models of learning. One such learning model is as developed by Phil Winne and Allyson Hadwin. This model is based on the opinion that the learner is the agent. Agency is the capacity to coordinate the various learning, motivation, and emotional skills to achieve the goals. Based on this model, the self-regulated learner applies the agency when they are involved in four major stages of cycles: analyzing tasks, setting goals and designing plans, engaging in learning, and adapting learning approaches.

At the stage of analyzing assignments, learners examine whatever information they deem relevant to construct an understanding of what their tasks are, what resources they should have, and how they feel about the tasks they will be doing. In relation to the second stage, setting goals and designing plans, learners should know the purpose of the lesson, how to achieve that goal, and what consequences accompany the outcome. In achieving that goal, consider the steps to complete the task, what learning skills are needed, and pay attention to the task with similar things that have been done before. In the third stage, applying tactics and strategies to accomplish the tasks are several things to note, such as retrieving previously existing knowledge in memory, examining existing information, applying cognitive operations, monitoring products, and managing cognitive loads. The last stage is regulating learning. At this stage, the learner decides whether changes need to be made at any earlier stage. For example, if the learning is slow, then whether it takes a friend to learn or need to make improvements to the activities at each stage before.

The stages of self-regulated learning require consistency to be applied properly. Consistency is very necessary so that the learning model can provide maximum benefits. In fact, to make learning more interesting and useful, this model can be developed and improved.

\section{CONCLUSION}

Based on previous exposures, it can be concluded as follows. English writing skills require serious effort and practice in compiling, developing, and analyzing ideas. This will work smoothly if supported by appropriate strategies, techniques, and writing skills. In addition, the learner should have sufficient experience of what is written and knowledge of the science/foundation of the language. In learning English writing skills, it is necessary to know and learn first about the English grammar and vocabulary. Next do various processes in writing, like choosing topics, brainstorming, outline, drafting, review, revising, editing, and so on. The self-regulated learning model can enhance the motivation of learning because this model encourages students to acquire knowledge and skills on their own voluntarily. Therefore, the role of teacher/mentor is very important. The implementation of self-regulated learning has a positive relationship with the development of English writing ability. Students who have good self-regulated learning tend to develop their English writing skills smoothly and well. In other words, students who have high self-regulated learning will have good learning results as well. In addition, students with self-regulation at a high level will have good control in achieving their academic goals. In fact, self-regulated learning will help learners always to be able to learn calmly, comfortably, seriously, and without ever getting bored Learning becomes a necessity that is always necessary wherever and whenever.

\section{ACKNOWLEDGMENT}

Acknowledgments the researcher conveyed to the my colleagues who provided insight and expertise that greatly assisted the research of this paper.

\section{REFERENCES}

1. Kusumandari, Rafika Bayu \& Istyarini, Character Education Development Model-based E-Learning and Multiple Intelegency in Childhood in Central Java, Global Journal of Computer Science and Technology: H Information \& Technology Volume 15 Issue 3 Version 1.0 Year 2015

2. Georgescu, Corina Amelia dan Cristina Ungureanu. 2012. Learner's Strategies in Language Learning. Procedia-Social and Behavioral Sciences, Vol. 46, pp. 5000-5004

3. Susanti, Arik. 2001. Pengembangan Model Pembelajaran Kooperatif Tipe CIRC Untuk Meningkatkan 
Kemampuan Menulis Bahasa Inggris Mahasiswa D3 Administrasi Negara FIS Unesa. Jurnal Nasional.

4. Syamsi, Kastam. 2003. Mencari Alterantif Model Pembelajaran Bahasa berbasis Kompetensi. Makalah Seminar Nasional Bahas, Seni dan Pembelajarannya.

5. Flowerdew, Joh. 1999. Problems in Writing for Scholarly Publication in English: The Case of Hongkong. Journal of Second Language Writing, Vol. 8 (3), pp: 243-264.

6. Truscott, John. 1996. Review Article: The Case Against Grammar Correction in L2 Writing Classes. Language Learning, Vol. 46, No. 2, pp. 327-369.

7. Guenette, Danielle. 2007. Is Feedback Pedagogically Correct? Research Design Issues in Studies of Feedback on Writingi. Journal of Second Language Writing, Vol 16, pp. 40-53.

8. Yamat, Hamidah dan Farinaz Shirani Bidabadi. 2010. Learning Styles Prefrences by Iranian EFL Freshman University Students. Procedia-Social and Behavioral Sciences, Vol. 7, pp.219-226.

9. Gredler, Margaret E. 2011. Learning And Instruction Teori dan Aplikasi terjemahan Triwidodo. Jakarta: Kencana Prenada Media.

10. Woolfolk, Anita. 2009. Educational Psychology. Active Learning Edition Terjemahan Helly Prajitno Soetjipto Yogyakarta: Pustaka Pelajar.

11. Bandura, Albert. 1997. Self Efficacy: The Exercise of Control. New York: W.H. Freeman dan Company.

12. Powers, Matthew N. 2017. Self Regulated Design Learning London dan New York: Roudledge Taylor and

13. Powers, Matthew N. 2017. Self Regulated Design Learning London dan New York: Roudledge Taylor and Francis Group.

14. Denzin, N., \& Lincoln. Y.(1994). Handbook of Publications Inc.

15. Zahed-Babelan, Adel dan Mahdi Moenikia. 2010. The Role of Learning Styles in Second Language Learning among Distance Education Students. Procedia-Social and Behavioral Sciences, Vol. 2, pp.1160-1173.

16. Chand, Zakia Ali. 2014. Language Learning Strategy Use and Its Impact on Proficiency in Academic Writing of Tertiary Students. Procedia-Social and Behavioral Sciences, Vol. 118, pp.511-521

17. Taylor, Gordon. 2009. A Student's Writing Guide. Cambridge: Cambridge University Press.

18. La Abo. 2016. Model Pembelajaran Menulis yang Efektif. Bandung: Mujahid Press.

19. Swick, Ed. 2009. Writing Better English. New York: Mc Graw Hill.

20. Fitzpatrick, Mary. 2005. Engaging Writing. USA: Longman

21. Raimes, Ann. 1983. Techniques in Teaching Writing. New York: Oxford University Press

22. Raimes, Ann. 1983. Techniques in Teaching Writing. New York: Oxford University Press

23. West, Christ. 2008. Perfect Written English. Great Britain: Random House Books

24. Bandura, Albert. 1997. Self Efficacy: The Exercise of Control. New York: W.H. Freeman dan Company.

25. Powers, Matthew N. 2017. Self Regulated Design Learning London dan New York: Roudledge Taylor and Francis Group.

26. Zumbrunn Sharon, dkk. 2011. Encouraging Self Literature. Virginia: Metropolitan Educational Research Consortium

27. Bramuci, Annarita. 2013. Self-Regulated Learning. Macerata: Lifelong Learning

28. Panadero, Ernesto. 2017. A Review of Self Regulated Learning: Six Models and Four Directions for Research. Francis Group. Qualitative Research.Thousand Oaks, CA, US: Sage Regulated Learning in the Classroom: A Review of the

Frontiers in Psychology, April 2017, Vol. 8, Article 422, pp. 1-28

29. Daniela, Popa. 2015. The Relationship between self regulation, Motivation, and Performance at Secondary School Students. Procedia-Social and Behavioral Sciences, Vol. 191, pp.2549-2553

30. Bramuci, Annarita. 2013. Self-Regulated Learning. Macerata: Lifelong Learning

31. Woolfolk, Anita. 2009. Educational Psychology. Active Learning Edition Terjemahan Helly Prajitno Soetjipto . Yogyakarta: Pustaka Pelajar

32. Powers, Matthew N. 2017. Self Regulated Design Learning London dan New York: Roudledge Taylor and Francis Group

33. Ferreira, Paula Costa dan Ana Malgarida Veiga Simao. 2012. Teaching Practices that Foster Self Regulated Learning: A Case Study. Educational Research eJournal, Vol. 1, No. 21, pp. 1-16

34. Ringdal Alyssa dan Daniel C. Moos. 2012. Self Regulated Learning in the Classroom: A Literature Review on the Teacher's Role. Hindawi Publishing Corporation. Education Research International, Vol. 2012, Article ID 423284, pp. 1-15

35. Wolters, C.S., Pintrich P. R., dan Karabenick, S. A 2003. Assessing Academic Self-Regulated Learning. Conference on Indicators of Positive Development Child Trends

36. Zimmerman, Barry. 2012. Becoming a Self-Regulated Learner: an Overview, Theory to Practice. Journal of Educational Psychology, Vol. 86 (3), 2012.

37. Wolters, C.S., Pintrich P. R., dan Karabenick, S. A 2003. Assessing Academic Self-Regulated Learning. Conference on Indicators of Positive Development Child Trends

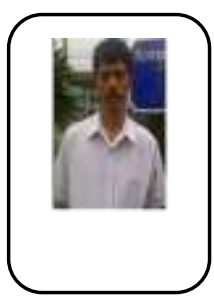

\section{AUTHORS PROFILE}

Laode Nggawu, Lecturer at Universitas Halueleo Makasar Indonesia.

Developing Learning Tools in the Improvement of Learning Outcomes in TOEFL ITP Preparation Training, Competency Enhancement in Web Designing By Using Project Based Learning, Development of Mathematics Teacher Competencies, Knowledge Management to Improve Performance and Excellence of Educational Institutions; Best Practices Performance Technology: Concepts and Applications in Learning Organizations, Employment Analysis in the Renewable Energy Sector, Vocational Education and Training: An Overview. Development of Collaborative-Creative Learning Using Virtual Models, Laboratory Media for Instrumental Analytic Chemistry Lectures.

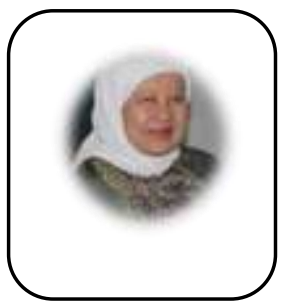

Hartati Muchtar. Professor at Universitas Negeri Jakarta. Secretary of S2 and S3 Education Technology, Coordinator S2 and S3 Education Technology Jakarta State University. Research with title: Development of a semantic differential attitude scale on calculus, application of performance assessment in profesiona competency test of participants in vocational school of beauty therapist, The Effect of Flipped Classroom and Problem Based Learnin Strategies in High School, the effects of instructional strategies and science process skill on biology toward students achievement in mts mu'allimat NW Pancor, the effect of problem based learning and self efficiency for improving learning outcomes in pshychiatric nursing education, Application of authentic assessment in an effort to improve the quality of education for Jakarta state university professors, The Effect of Metacognitive Learning Strategies and Cognitive

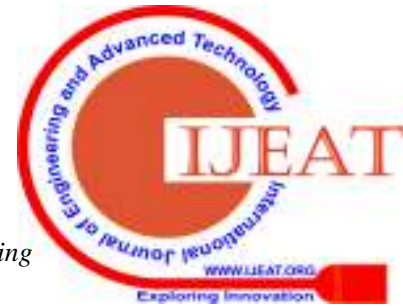


International Conference on Recents Advancements in Engineering and Technology (ICRAET-18) |15th and 16th March 2019|Siddhartha Institute of Technology \& Sciences, Telangana, India

Styles on Students' Mathematical Problem Solving Abilities (Exsperiment on Madrasah Tsanawiyah, Wanasaba District, East Lombok), Application of Authentic Assessment in Education Quality Improvement Efforts, the effect of teaching strategy using PhET interactive simulation and information technology literacy on students conceptual understanding of work and energy, an analysis of ict implementation in the learning process at the islamic boarding school of nurul haramain nw narmada west lombok regency, analytical descriptive study of the level of "concern" of social sciences teachers against innovation, game for learning.

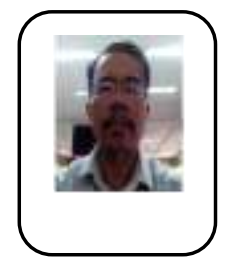

Khaerudin, Lecturrer at Universitas Negeri Jakarta, Jakarta Permanent and daily lecturers teach and guide the Thesis and Dissertation of postgraduate students in the Educational Technology Departement Universitas Negeri Jakarta and Universitas Terbuka. Get an Award Robert deKieffer International Fellowship Award" dari Association for Educational Communication Technology (AECT) International Division.. Some of the books produces include Modern Instructional Design. Instructional Design. Modern Instructional Design: Guiance for Educators and Educational Innovators. Interactive Learning Models. Training Program Evaluation. Distance Education: Theory and Practice. Educational Technology to Improve Quality and Access on A Global Scale. Writing Teaching Materials in Higher Education. The program for developing the basic skills of instructional techniques for young lecturers: instructional design. The program for developing basic instructional techniques for young lecturers: outlines of teaching programs and teaching program units. Pekerti: Teach at College, Book 1.08. Learning Analysis. Open University management and development system. Information sharing model, learning model through experience, problem solving model. The main guidelines for writing teaching materials at the University. Guide to Education Teachers and innovators. Teaching in Higher Education: instructional design. Educational Technology in Distance Education. Interactive Learning Models, Digital image processing and programming techniques. The basic concept of curriculum development.

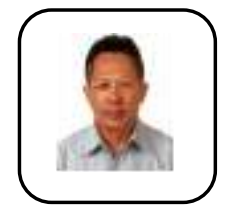

M. Syarif Sumantri. Professor in Educational Technology, Postgraduate Program, Universitas Negeri Jakarta. Permanent daily lecturers teach and guide the Thesis and Disertation of postgraduate student in the Educational Technology Departement, Universitas Negeri Jakarta. Some of the studies carried out include: Improving Mathematical Learninf Results with Student Blended Learning and Achievement Motivation, The effect of grant block programs on life acquisition to English learning results. Relation between independent learning and echievement motivation with Islamic Religion Education Learning Outcomes in SMP Terbuka. Effectiveness of Learning Strategy and Learning Style on Learning Outcome. Relation between Module Readability and Motivation Achieving The Learning Outcomes of Accounting Subjects in SMA Terbuka. Learning based Multiple Intelegence 